\title{
Impact of rehabilitation exercises program on adductor muscle strain \\ ${ }^{1}$ Dr/ Islam Amin Zaki Abdelwakel Introduction
}

Adductor muscle strains are much more detected in football than other sports. (Timothy Tyler et al., 2014), (Jonas Werner et al., 2009), (Lynch and Renstrom, 1999), (Ekstrand and Gillquist, 1983). The Adductors are a group of muscles in the inner thigh that operate in order to contribute flexion, adduction and rotation of the hip joint. (Marieb, 2000), (Calais-Germain, 1993). The Football sport demands a strong eccentric contraction of the adductor muscle while the game and the practice. (John Orchard et al., 2000).

Adductor muscle strains constantly occurs in football that require repetitive skills such as sudden changes in direction, twisting, turning, and kicking. (Geoffery et al., 2007), (Per Hölmich, 2007), (Morelli and Weaver, 2005), (Lars \& Per, 2002), (Anderson et al., 2001). About 10-13\% of all injuries per year in Football sport has been reported in the groin region. (Arni Arnason et

al., 2004), (Hawkins et al., 2001).

Adductor muscle strains is a tear or partial tear to any one of the adductor muscles causing pain in the inner thigh. The rank of this injury can start from the mild to the severe one. (Lars \& Per, 2002).

It has been indicated that the definite occurrence of adductor muscle strains in sport is anonymous. This is due to that the players are not constantly informing their minor groin pain. (Timothy Tyler et al., 2014). Where several studies have shown that intrinsic risk factors in football such as previous groin injury especially when treatment program is insufficient, age, poor flexibility of the hip joint and lacking strength of adductor muscles, overload training, muscle imbalance, and fatigue are considered as a risk factor for injuries. (Martin Hägglund et al., 2006), (Arni Arnason et al., 2004), (Carolyn and Willem, 2001), (Darin T.

1 Associate Prof. Gymnastic and Exercise Department, Faculty of Physical Education for Men, Alexandria University, Egypt Assiut Journal For Sport Science Arts 
Leetun. Et al., 2004), (Sallie Cowan et al., 2004), (Timothy F. Tyler. Et al., 2001), (Carolyn A. Emery. 1999), (Han Inklaar et al., 1996).

The basic features of this injury is a sudden sharp pain in the inner thigh area, either in the middle of the muscle or higher up where the origin of the tendon adhere to the pelvic bone. When sprinting or changing direction quickly the player may or may not be able to play on depending on how severe the pain is. (Peter and Karim, 2012), (Karen Bellenir, 2008), (Lars \& Per, 2002).

$90 \%$ of the majority of injuries in the hip and groin region in high level of football game can take at least 4 weeks to recover. But if the injury "Adductor muscle strains" is not well treated or the player is returned too quickly to practice, in this case the injury might develop into a longstanding or may include features consistent with a chronic pain state. (Jonas Werner et al., 2009), (Per Hölmich, 2007).

Further entangling this injury is the scarcity of agreement throughout therapists on the permissible management of athletic groin pain. The study by (Geoffery Verrall. et al., 2007) has been reported that all patients were treated with rest from active weight bearing activities for the first 3 month. Other study by Cristina Rodriguez, et al. (2001) declared that the treatment program has been started with cryotherapy, ultrasound, laser and pharmacology for first two weeks, then an exercise program has been started with flexibility and smooth strengthening of the hip adductor muscles. Another study by Wollin $\mathrm{M}$ and Lovell G. (2006) reported that a program of graduated abdominal and pelvic strengthening exercises has been applied for 3 month.

In general many studies declared that the effectiveness of exercise therapy as a treatment of groin injury has been assumed that exercise therapy program is a main factor in rehabilitation phase. (Timothy Tyler et al., 2014), (Mohammad, W. S. et al., 2014), (Weir, a. et al., 2011), (Jansen, J. et al., 2010), (Zuzana Machotka \& Saravana Kumar, 2009), (Wollin M, and Lovell G., 2006), (McCarthy A, and Vincenzino B., 2003), 
(Timothy F. Tyler. et al., 2002), (Per Hölmich, et al., 1999).

Exercises are defined as a set of specific movements with the objective of developing and training the muscle and joints with the use of a practice routine or physical training in order to restore range of motion, restore strength, and return function. (Daniele L. at al., 2012).

The purpose of this study was to evaluate the effects of the exercise program on flexibility and muscle strength of football players with adductor pain.

\section{Terminology}

Methods

Objective: To examine the effect of exercise therapy program on flexibility and pelvice strength muscles for football players with adductor muscles strain in reducing pain and disability.

Design: Randomized controlled trial.

Setting: All participants are football players suffering of adductor muscles pain

\section{Participants}

Four subjects with adductor pain participated in this study (Table 1). They received verbal and written information about the study and all gave their written consent before entering the study.

Table (1)

Description of the participants' injury.

\begin{tabular}{|c|c|}
\hline Type of sport & Football \\
\hline Gender & 4 Males \\
\hline Level of sports & Football League Second Division \\
\hline Practice/games & $\begin{array}{l}\text { Training four time per week, competition } \\
\text { once a week }\end{array}$ \\
\hline Injury type & Adductor muscles strain "partial tear" \\
\hline $\begin{array}{l}\text { Injury history } \\
\text { (re-injury) }\end{array}$ & $\begin{array}{l}\text { In the recent season. } 2 \text { players had this injury } \\
\text { two times "recurrence injury", another player } \\
\text { had this injury just one time, and the last } \\
\text { player did not face this injury. }\end{array}$ \\
\hline
\end{tabular}

Follow Table (1)

Description of the participants' injury.

Assiut Journal For Sport Science Arts 


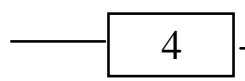

\begin{tabular}{l|l}
\hline \hline \multicolumn{1}{c|}{ Type of sport } & \multicolumn{1}{c}{ Football } \\
\hline \hline Injury duration & One month \\
\hline Injury location & Groin region \\
\hline Clinical examination & $\begin{array}{l}\text { Pain at resisted adduction and palpation of } \\
\text { the groin area “ }\end{array}$ \\
\hline Imaging & X-ray \\
\hline Treatment suggestion & $\begin{array}{l}\text { Rest 2 weeks "no activity", medications, } \\
\text { physiotherapy. }\end{array}$ \\
\hline Referred by & General practitioner \\
\hline $\begin{array}{l}\text { pain score "VAS" }(0- \\
10)\end{array}$ & $8-7$ \\
\hline \hline
\end{tabular}

All participants "were matched based on age, height and weight, which is presented in Table 2.

\section{Table (2)}

\section{Means and Standard Deviations of Characteristics of subjects at} the baseline.

\begin{tabular}{l|c|c|c}
\hline \hline \multirow{1}{*}{$\begin{array}{c}\text { Statistics } \\
\text { Parameters }\end{array}$} & \multicolumn{2}{|c|}{ participants $(\mathbf{n}=4)$} & \multirow{2}{*}{ Skewness } \\
\cline { 2 - 3 } \multicolumn{1}{c|}{ Mean } & SD \pm & \\
\hline \hline Age $(\mathrm{y})$ & 20.25 & 0.95 & -0.85 \\
\hline Height $(\mathrm{cm})$ & 175.71 & 4.71 & 0.65 \\
\hline Wight $(\mathrm{kg})$ & 69.77 & 8.16 & -0.01 \\
\hline BMI & 23.25 & 1.68 & -0.59 \\
\hline \hline
\end{tabular}

Values are expressed as the mean \pm standard deviation (SD)

Shown in Table (2) special characterization statistical sample of variables (age, height, weight, BMI) the values of these variables moderate and characterized by normal distribution. Where skewness of those variables is close to zero. Which confirms moderation of variables before the experiment.

Main Outcome Measures:
All measurements were performed before and one day after the intervention. In order to reduce measurement errors, assessments were conducted by the same investigator in the same place before and after the intervention.

\section{1- Physical}

Fitness

\section{Measurements}

Physical fitness parameters included 
1- 50-meter running test. (Erlangen J. W., 2003)

2- Adductor muscular strength. Hand-Dynamometer (Kristian Thorborg. et al., 2010)

3- Hip flexibility test "Goniometer". (Antonio Cejudo et al., 2015)

\section{2- Outcome Measures}

To assess the degree of pain visual analogue scale (VAS) was used. (McCaffery M., 1999).

\section{Interventions:}

The program included two phases respectively "4 weeks for each". Each phase included three sessions per week. The program has been applied within the time period April and May 2016.

\section{Phase one:}

\section{Low Intensity of Interval} Training was used for strengthen the adductor and lower abdominal muscles. The intensity of exercise used in this way no more than medium intensity $60 \%$ of the individual maximum level, repetition of each exercise for approx. 10 times for three sets, and the rest periods ranging from 60 seconds to 120 seconds (Erlangen, 2003).

The subjects conducted the exercise program for approx. 45- 60 minutes in total, 3 times a week, for 4 weeks. This program is divided into 3 categories: 7-10 min warm up "bike-ergometer, followed with a strength exercises and 30-40 min and then cool down 10 min stretching exercises.

Static Stretching Exercises have been done by the players themselves during the times of practicing and at the end of each sessions. The muscle to be stretched "adductor muscles" is lengthened slowly to inhibit the firing of stretching reflex and held in a comfortable range for 15 to 30 s. (McAtee, R. E. 1993).

\section{Phase two:}

Pyramid Training has been applied. The intensity of exercise used in this way from $60-100 \%$ of the individual maximum level. Repetition of each exercise for approx. 10 times for $4-5$ sets, and the rest periods ranging from $1-2$ min. (Erlangen, 2003).

All strength exercise in this phase consisted of a low load exercise with resistance adjusted by using the elastic band of different resistances. Each session in the suggested program began and ended with an assessment of the patient's progress by using the VAS, 
just to evaluate the pain level (pre- and post-treatment each session). Measurements for all suggested exercises (for each subject) must be carried out to determine the maximum load for strength training.

In this phase PNF stretching "Proprioceptive neuromuscular facilitation" has been used for hip-flexibility and stretching the adductor muscles (It has been applied after four weeks in order to ensure that the absence of pain at all participants.). Hold-Relax method was used. (Erlangen, 2003), (McAtee, R. E. 1993).

The following table shows the distribution of the volume, intensity and the rest interval throughout the suggested program. The suggested program was conducted individually for all subjects. (Enclosure Nr.4 \& 5).

Table (3)

The volume, intensity and the rest interval throughout the suggested program.

\begin{tabular}{|c|c|c|c|c|}
\hline Phase & week & Sessions & load intensity & $\begin{array}{c}\text { rest } \\
\text { between sets }\end{array}$ \\
\hline \multirow{4}{*}{ One } & 1 & 1,2 and 3 & \multirow{2}{*}{$\begin{array}{l}40-50 \% \text { of maximum } \\
\text { repetition }\end{array}$} & \multirow[b]{2}{*}{$1 \mathrm{~min}$} \\
\hline & 2 & 4,5 and 6 & & \\
\hline & 3 & 7,8 and 9 & \multirow{2}{*}{$\begin{array}{c}50-60 \% \text { of maximum } \\
\text { repetition }\end{array}$} & \multirow[b]{2}{*}{$1 \mathrm{~min}$} \\
\hline & 4 & $\begin{array}{l}10,11 \text { and } \\
12\end{array}$ & & \\
\hline \multirow{4}{*}{ Two } & 5 & $\begin{array}{l}13,14 \text { and } \\
15\end{array}$ & \multirow{2}{*}{$\begin{array}{c}60-70 \% \text { of maximum } \\
\text { repetition }\end{array}$} & \multirow{2}{*}{$1-2 \min$} \\
\hline & 6 & $\begin{array}{l}16,17 \text { and } \\
18\end{array}$ & & \\
\hline & 7 & $\begin{array}{l}19,20 \text { and } \\
21\end{array}$ & \multirow{2}{*}{$\begin{array}{c}70-80 \% \text { of maximum } \\
\text { repetition }\end{array}$} & \multirow{2}{*}{$1-2 \min$} \\
\hline & 8 & $\begin{array}{l}22,23 \text { and } \\
24\end{array}$ & & \\
\hline
\end{tabular}

Data Analyses

Statistical analyses were performed using SPSS v20.0. Values are presented as mean \pm SD. The level of probability was set at $\mathrm{p}<0.05 \& \mathrm{p}<0.01$.

\section{Results}

In comparison of adductor muscles strength and range of motion for nondominant and dominant legs at baseline the result showed 
superiority of non-dominant leg to the dominant leg. Table 2.

After 8 weeks of exercises program adductor muscular strength increased significantly in dominant leg (from $9.66 \pm 0.30$ to 35.82 $\pm 0.34)$ and the percentage of development reached $100 \%$, where the value of $(\mathrm{T})$ reached 197.09 ( $p<0.01)$. Similarly for the non-dominant leg the result showed that there were slight significant differences from $33.50 \pm 0.81$ to $36.40 \pm 0.92$ $(\mathrm{p}<0.05)$ and the percentage of development reached $8.65 \%$ where the value of $(\mathrm{T})$ reached $8.77(\mathrm{p}<0.05)$.

Similarly significant difference were observed in range of motion test for the dominant leg. Where the result showed the difference between Test 1 "at baseline" and Test 2 "after 8 weeks" (from $20.80 \pm 0.57$ to
$51.82 \pm 0.50)$, where the value of $(\mathrm{T})$ reached $73.68(\mathrm{p}<0.01)$. For the non-dominant leg the result showed inconsiderable significant differences between Test 1 and Test 2 (from 48.75 \pm 0.26 to $51.40 \pm 0.65$ ), where the value of $(\mathrm{T})$ reached 7.71 $(\mathrm{p}<0.05)$.

After 8 weeks of exercises program pain level "VAS scores decreased significantly in dominant leg (from $7.75 \pm 0.50$ to 0.25 $\pm 0.50)$ where the value of $(\mathrm{T})$ reached $(-25.98)(\mathrm{p}<0.01)$, and the percentage of development reached $96.77 \%$. Similarly for $50 \mathbf{~ m}$. (speed test) the result showed that there were significant differences from $10.78 \pm 0.13$ to $6.52 \pm 0.11$, where the value of $(\mathrm{T})$ reached $(-45.61)(\mathrm{p}<0.01)$.

\begin{tabular}{|c|c|c|c|c|c|c|c|c|c|}
\hline \multirow{2}{*}{ Parameters } & \multirow{2}{*}{ unit } & & \multicolumn{2}{|c|}{ Baseline test } & \multicolumn{2}{|c|}{ Post test } & \multirow{2}{*}{$\begin{array}{l}\text { Value } \\
\text { (T) }\end{array}$} & \multirow{2}{*}{$\begin{array}{l}\text { Sig. } \\
\text { level }\end{array}$} & \multirow{2}{*}{$\begin{array}{l}\begin{array}{l}\text { Rete } \\
\text { of } \\
\text { better }\end{array} \\
\end{array}$} \\
\hline & & & Mean & $\mathrm{SD} \pm$ & Mean & $\mathrm{SD} \pm$ & & & \\
\hline \multirow{2}{*}{$\begin{array}{l}\text { Adductor } \\
\text { muscles } \\
\text { strength }\end{array}$} & \multirow[t]{2}{*}{ LBS } & $\begin{array}{c}\text { Non- } \\
\text { dominant } \\
\text { leg }\end{array}$ & 33.50 & 0.81 & 36.40 & 0.92 & $8.77 *$ & 0.03 & $\begin{array}{c}8.65 \\
\%\end{array}$ \\
\hline & & $\begin{array}{c}\text { dominant } \\
\text { leg }\end{array}$ & 9.66 & 0.30 & 35.82 & 0.34 & $\begin{array}{c}197.09 \\
* *\end{array}$ & 0.01 & $\begin{array}{c}100 \\
\%\end{array}$ \\
\hline ROM & angle & $\begin{array}{c}\text { Non- } \\
\text { dominant } \\
\text { leg }\end{array}$ & 48.75 & 0.26 & 51.40 & 0.65 & $\begin{array}{c}7.71 \\
* *\end{array}$ & 0.01 & $\begin{array}{c}5.43 \\
\%\end{array}$ \\
\hline \multirow{2}{*}{ Parameters } & \multirow{2}{*}{ unit } & & \multicolumn{2}{|c|}{ Baseline test } & \multicolumn{2}{|c|}{ Post test } & \multirow{2}{*}{$\begin{array}{l}\text { Value } \\
\text { (T) }\end{array}$} & \multirow{2}{*}{$\begin{array}{l}\text { Sig. } \\
\text { level }\end{array}$} & \multirow{2}{*}{$\begin{array}{l}\begin{array}{l}\text { Rete } \\
\text { of } \\
\text { better }\end{array} \\
\end{array}$} \\
\hline & & & Mean & $\mathrm{SD} \pm$ & Mean & $\mathrm{SD} \pm$ & & & \\
\hline
\end{tabular}




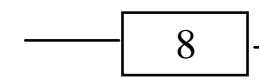

\begin{tabular}{l|l|l|l|l|l|l|l|l|l}
\hline & & $\begin{array}{l}\text { dominant } \\
\text { leg }\end{array}$ & 20.80 & 0.57 & 51.82 & 0.50 & $\begin{array}{l}73.68 \\
* *\end{array}$ & 0.01 & $\begin{array}{l}100 \\
\%\end{array}$ \\
\hline $50 \mathrm{~m}$. & sec. & & 10.78 & 0.13 & 6.52 & 0.11 & $\begin{array}{l}-45.61 \\
* *\end{array}$ & 0.01 & $\begin{array}{l}39.51 \\
\%\end{array}$ \\
\hline VAS & score & & 7.75 & 0.50 & 0.25 & 0.50 & $\begin{array}{l}25.98 \\
* *\end{array}$ & 0.01 & $\begin{array}{l}96.77 \\
\%\end{array}$ \\
\hline
\end{tabular}

$* \mathrm{P}$ value $<0.05$

$* * \mathrm{P}$ value $<00.1$

\section{Discussion}

The results of this study reinforce the approval of the effectiveness to use exercise therapy as a treatment for football players with adductor muscles strain to reduce the pain and disability. (Timothy Tyler et al., 2014), (Mohammad, W. S. et al., 2014), (Weir, a. et al., 2011), (Jansen, J. et al., 2010), (Zuzana Machotka \& Saravana Kumar, 2009), (Wollin M, and Lovell G., 2006), (McCarthy A, and Vincenzino B., 2003), (Timothy F. Tyler. et al., 2002), (Per Hölmich, et al., 1999).

All adductor muscles cause flexion and rotation, as the adductors are stabilizers for the hip joint. They are endangered to injury if stabilization is disturbed through muscle imbalance, lack of flexibility, muscular fatigue or overload. The results were also in agreement with previous studies that demonstrated that pain can be reduced by an exercise program which started with flexibility and graduated abdominal and pelvic strengthening exercises. (Wollin $\mathrm{M}$ and Lovell $\mathrm{G}$. 2006), (Cristina Rodriguez, et al. 2001).

In the recent study, the adductor pain significantly improved after 8 weeks of exercise intervention in all subjects. This indicates that the program caused the changes in VAS. This result was in agreement with previous studies (Timothy Tyler et al., 2014), (Alison Quinn, 2010).

The result of Range of Motion (ROM) in the hip joint showed the differences between pre and post test. This is similar to the results of (Timothy Tyler et al., 2014), (Alison Quinn, 2010), (Arni Arnason et al., 2004), (Timothy Tyler. et al., 2001).

Assiut Journal For Sport Science Arts 
The exercise program, which was suggested in this study included flexibility and strength exercises for groin region. It includes also lower abdominal muscles strengthen. The result of adductor muscles strength showed significant improved, that indicates that the flexibility and strength exercises have a positive impact on all adductor muscles group. The results were also in agreement with previous studies (Timothy Tyler et al., 2014), (Zuzana Machotka \& Saravana Kumar, 2009), (Wollin $\mathrm{M}$ and Lovell G. 2006), (Cristina Rodriguez, et al. 2001).

There are many other tests that can be carried out for measuring the functional improvement, but the studies done by Peter and Karim (2012), and Karen Bellenir (2008), Darin T. Leetun. Et al. (2004), Sallie Cowan et al. (2004), and Timothy F. Tyler. Et al. (2001) declaired that the players with adductor muscles pain may not be able to sprinting which indicates the symptoms of this injury. In the recent study, 50-Meter sprinting test was applied to measure the disability of all subjetcs. The result showed that there were significant differences between pre and post test.

\section{Conclusion}

Based on the results, the suggested exercise program seems to be effective for the treatment and prevention of players from adductor muscles pain. However, a limitation of this study is not possible to generalize the results due to relatively small sample. Moreover, the adductor muscles pain such as mild, moderate or severe pain may influence the muscle activities after exercise program. As such, it is recommended to deal with such kind of studies among large number of samples, and there should be follow-up studies for tracing the impact of these studies on the long run.

\section{References}

1- Alison Quinn. (2010). Hip and Groin Pain: Physiotherapy and Rehabilitation Issues. The Open Sports Medicine Journal., 4, 93-107.

2- Anderson K, Strickland SM, Warren R. (2001). Hip and groin injuries in athletes. American Journal of Sports Medicine., Vol.29: 521-33.

3- Antonio Cejudo, Francisco Ayala, Pilar Sainz De 
Baranda, Fernando Santonja. (2015). Fernando Santonja: Reliability of two methods of clinical examination of the flexibility of the hip adductor muscles. . The International Journal of Sports Physical Therapy., Vol. 10 (976-983).

4- Arni Arnason, Stefan B. Sigurdsson, Arni Gudmundsson, Ingar Holme, Lars Engebretsen, and Roald Bahr. (2004). Risk factors for injuries in football. American Journal of Sports Medicine., 32 (Suppl1):5S-16S.

5- Calais-Germain, B. (1993). Anatomy of Movement. Eastland Press. ISBN 0939616-17-3.

6- Carolyn A. Emery and Willem H. Meeuwisse. (2001). Risk factors for groin injuries in hockey. . Medicine \& Science in Sports \& Exercise., 33:1423-1433.

7- Carolyn A. Emery. (1999). Does decreased muscle strength cause acute muscle strain injury in sport? A systematic review of the evidence. Physical Therapy Reviews Journal., Vol.4 (3):141-151.

8- Cristina Rodriguez, Antonio Miguel, Horacio Lima, and Kristinn Heinrichs
- (2001). Osteitis pubis syndrome in the professional soccer athlete: a case report. Journal of Athletic Training, 36(4):437-40.

9- Daniele Tatiane Lizier, Marcelo Vaz Perez, Rioko Kimiko Sakata. (2012. Exercises for Treatment of Nonspecific Low Back Pain. Revista Brasileira de Anestesiologia., 6: 838-846.

10- Darin T. Leetun, Mary Lioyd Ireland, John D. Willson, Bryon T. Ballantyne, Irene McClay Davis. . (2004). Core stability measures as risk factors for lower extremity injury in athletes. Medicine \& Science in Sports \& Exercise. , 36:926934.

11- Ekstrand J, Gillquist J. . (1983). The avoidability of soccer injuries. . Inter $\mathrm{J}$ of Sports Med., 4(2):124-128.

12- Erlangen, J. W. (2003). Optimales Training, Leistungsphysiologische Trainingslehre unter besonderer Beruecksichtigung des Kinder- und Jugendtrainings. Nuernberg. 13. Auflage.: Spitta Verlag.

13- Geoffery M. Verrall, John P. Slavotinek, Gerald T. Fon, and Peter G. Barnes. (2007). Outcome of 
conservative management of athletic chronic groin injury diagnosed as pubic stress injury. . American Journal of Sports Medicine., 35(3):46774.

14- Geoffery M.Verrall, John P. Slavotinek, Gerald T. Fon, and Peter G. Barnes. . (2007). Outcome of conservative management of athletic chronic groin injury diagnosed as pubic bone stress injury. . American Journal of Sports Medicine., Vol.35: 467-74.

15- Han Inklaar, Bol E, Sandor L. Schmikli, Mosterd WL. (1996). Injuries in male soccer players: team risk analysis. . International Journal of Sports Medicine. , Vol.17:229-234.

16- Hawkins RD, Hulse MA, Wilkinson C, Hodson A, Gibson M. . (2001). The association football medical research programme: an audit of injuries in professional football. British Journal of Sports Medicine., 5: 43-47

17- Jansen, J., Poot, B., Mens, J. M. A., Backx, F. J. G., \& Stam, H. J. . (2010). The effect of experimental groin pain on abdominal muscle thickness. . The Clinical Journal of Pain, 26(4), 300-5.
18- John Orchard, John W Read, Geoffrey M Verrall, John P Slavotinek. (2000). Pathophysiology of Chronic Groin Pain in the Athlete. . Pathophysiology of Chronic Groin Pain in the Athlete., Vol. 1:1-16.

19- Jonas Werner, Martin Hägglund, Markus Waldén, and Jan Ekstrand. . (2009). UEFA injury study: a prospective study of hip and groin injuries in professional football over seven consecutive seasons. British journal of sports medicine., 43(13):103640.

20- Karen Bellenir. (2008). Sports Injuries Information for Teens : Health Tips about Acute, Traumatic, and Chronic Injuries in Adolescent Athletes. (2nd ed.). Detroit, MI, United States: Omnigraphics.

21- Kristian Thorborg, Jesper Petersen, S. Peter Magnusson, Per Hölmich. (2010). Clinical assessment of hip strength using a hand-held dynamometer is reliable. . Scandinavian Journal of Medicine and Science in Sport., 20: 493-501.

22- Lars Peterson, Per Renström. (2002). Verletzungen im Sport, Prävention und Behandlung. (3 
Auflage. ed.). Köln: Deutsche Ärzte-Verlag GmbH.

23- Lynch SA, Renstrom PA. - (1999). Groin injuries in sport: treatment strategies. Sports Med., 28(2):137-144.

Marieb, E. (2000). Essentials of Human Anatomy and Physiology. 6th Edition. Addison Wesley Longman. ISBN 0-8053-4940-5.

\section{4- Martin Hägglund,} Markus Waldén and Jan Ekstrand. (2006). Previous injury as a risk factor for injury in elite football: a prospective study over two consecutive seasons. British Journal of Sports Medicine. , 40:767-772. 25- McAtee, R. E. (1993). Facilitated stretching. PNF stretching made easy. Champaign. IL. USA: Human Kinetics.

26- McCaffery M. (1999). Pain management: problems and progress. In: McCaffery M, Pasero CL. Pain: clinical manual. . St. Louis: Mosby: 2nd ed.

27- McCarthy A, Vincenzino B. - (2003). Treatment of osteitis pubis via the pelvic muscles. . Manual Therapy , 8(4):257-60.

28- Mohammad, W. S., Abdelraouf, O. R., Elhafez, S. M., Abdel-Aziem, A. A., \&
Nassif, N. S. . (2014). Isokinetic imbalance of hip muscles in soccer players with osteitis pubis. . Journal of Sports Sciences, 32(10), 934-9.

29- Morelli V, Weaver V. . (2005). Groin injuries and groin pain in athletes. Part 1. . Primary Care, 32: 163-83.

30- Per Hölmich, Pernille Uhrskou, Lisbeth Ulnits, Inge-Lis Kanstrup, Michael Bachmann Nielsen, Anders Munch Bjerg, and Kim Krogsgaard. (1999.). Effectiveness of active physical training as treatment for long-standing adductorrelated groin pain in athletes: randomised trial. . The Lancet , 353: 439-443.

31- Per Hölmich. • (2007). Long-standing groin pain in sports people falls into three primary patterns, a "clinical entity" approach: a prospective study of 207 patients. British Journal of Sports Medicine. , Vol.41(4):247-252.

32- Peter Brukner and Karim QC Khan. (2012). Clinical Sports Medicine (4th Revised edition ed.). New York, United States: McGrawHill Education-Europe.

33- Sallie M. Cowan, Anthony G. Schache, Peter Brukner, Kim L. Bennell, 
Paul W. Hodges, Paul Coburn, and Kay M. Crossley. . (2004). Delayed onset of transversus abdominus in long-standing groin pain. Medicine \& Science in Sports \& Exercise, 36:2040-2045.

34- Timothy F. Tyler, Stephen J. Nicholas, Richard J. Campbell and Malachy $P$. McHugh. - (2001). The association of hip strength and flexibility with the incidence of adductor muscle strains in professional ice hockey players. . American Journal of Sports Medicine., Vol.29:124128.

35- Timothy F. Tyler, Stephen J. Nicholas, Richard J. Campbell, Sean Donellan, and Malachy $P$. McHugh. (2002). The effectiveness of a preseason exercise program to prevent adductor muscle strains in professional ice hockey players. . American Journal of Sports Medicine , 30: 680-83.

36- Timothy F. Tyler, Takumi Fukunaga, Joshua Gellert. (2014). Rehabilitation of soft tissue injuries of the hip and pelvis. The International Journal of Sports Physical Therapy. , Vol. 9 (6 ):785-797. 37- Weir, a., Jansen, J. a C. G., van de Port, I. G. L., Van de Sande, H. B. a, Tol, J. L., \& Backx, F. J. G. . (2011). Manual or exercise therapy for long-standing adductor-related groin pain: A randomised controlled clinical trial. Manual Therapy, 16(2), 148-154.

38- Wollin M, Lovell G. • (2006). Osteitis pubis in four young football players: a case series . Physical therapy Sport, 7:53-60.

39- Zuzana Machotka and Saravana Kumar . (2009). A systematic review of the literature on the effectiveness of exercise therapy for groin pain in athletes. . Sports medicine, arthroscopy, rehabilitation, therapy \& technology, Available from, http://www.ncbi.nlm.nih.gov/p ubmed/19331695. 